unexpected, such as facts about the domestication of the eland in Russia or the fact that polar bears are poor swimmers and sometimes get their back legs bitten by ringed seals. The valuable point that Dr Grzimek puts over time and time again is that even hard-pressed animals can make a rapid come-back if given a little encouragement. The pity is that the style is occasionally too bright and assertive for total credibility. As an example of book production, the book is almost faultless; it is a pleasure to open it.

JOHN HILLABY.

\title{
Wild Animals in an African National Park, by Rennie Bere.
} Deutsch, 18s.

Game wardens, when they retire, tend to write lengthy reminiscences in which their many original observations are difficult to sort out of a welter of how-the-lion-nearly-got-me yarns. Mr Bere escapes this fault completely. Instead of reminiscing he gives us pretty straight natural history, and whenever he is briefly aneedotal his stories all make a worthwhile point. Evidently assuming that the reader is quite untutored in nature study (which, alas, is still true of most people) the author tells us simply and clearly about the animals, and a few of the birds, that he met with during his years as Director and Chief Warden of the Queen Elizabeth and Murchison Falls National Parks in Uganda. I thought him particularly good on elephant, hippo, lion, crocodile and Uganda kob, but he writes of many others also. He recounts too the problems facing conservationists: the poaching, the overstocking of hippos and elephants, the lack of money that hinders so many sohemes. My only regret about the book is that it runs to only 91 pages, for I felt that the author had many more good things to say. A map is provided, and of the 25 photographs a particularly interesting one shows a monitor lizard making off with a crocodile's egg.

W. M. CONDRY.

The Story of Elsa, by Joy Adamson. Collins, Harvill, 30s.

The publishers have called this book: "The full story of Elsa and her cubs published for the first time in one volume." Well, it is, and it isn't. The three earlier books have all been compressed into 3,19 pages (marred only by bad proof-reading and occasional left-overs of repeitition) with a first-rate selection of photographs. The bare bones of this fantastic story are all there, told in Mrs Adamson's diary English ; but so much is totally lacking. The foster-care of Elsa, and then of Elsa's cubs, was centainly of exceptional emotional concern to everyone involved, and primarily to the author, but there is next to no self-analysis of this deeper side of things. I kept on feeling that the book had been written by some third panty who had scarcely ever seen a lion, let alone lived with one, loved one, lost one.

I personally would have welcomed more introspection, more conversational comments from someone who witnessed this remarkable man-animal involvement, and more from George Adamson who was half a conductor, half a second fiddle throughout the story. In these days of rigidly scientific behavioural studies it is fantastic, and refreshing, to read Joy Adamson's unashamed anthropomorphism-"Elsa came back very proud of herself," "she talked very agitatedly to them," "she was very nearly crying," "did she have any realisation of the extraordinary link she was between the two worlds?" Mrs Adamson is also prepared to give reasons for events where many behaviourists would fight shy of such conclusions-"Could it have been that she knew I was coming back?" "It is obvious that she was in love," "She went to sharpen her claws."

And yet this unique combination of Joy Adamson, George and Elsa managed to pull off a coup beween man and beast that has few, if any, equals. There was Elsa killing that buck a few yards away, or permitting 
the buffalo's throat to be slit in the midst of the fight, or being deliberately estranged and yet remaining a link, or introducing her cubs to mankind and passing on so much of her trust. Countless people have fostered young wild animals less successfully. They at least should have an inkling of the outstanding blend of devotion and affection which enabled the Elsa story, the book, the film, the legend, to become a part of history.

\section{ANTHONY SMITH.}

\section{A Continent for Science: The Antarctic Adventure, by} Richard S. Lewis. Secker \& Warburg, 48s.

Of all the continents Antarctica is much the poorest in living creatures; it has also the most indestructible and inhospitable landscape, and the smallest and most disciplined human population. Conservationists, therefore, have not been much concerned with it except for certain fringing areas used by marine-based colonies of seals and of birds, especially penguins, which have long been a familiar symbol of the Antarctic. Richard Lewis, an American science writer, has produced in this book of high-quality journalism an excellent, well-informed and thoughtful account of the present state of knowledge resulting from the immense recent research effort lavished on that continent. Whether the priority accorded to this vast international research expenditure has been justified, and how much might have been done with funds of this magnitude on areas of more direct interest to more people are matters of opinion on which there has been surprisingly little discussion, perhaps because nearly everyone well informed about the programme has some personal interest in its continuance, and because the real costs tend to be wrapped up with military budgets. In any case it is an impressive and well-managed enterprise, and other natural scientists have commented that a high proportion of the truly experimental research is biological, even though biology is a very junior partner here.

Unfortunately in terms of conservation this book is almost a dead loss. References to the history of sealing and whaling are brief and superficial, and only the foreword by $\operatorname{Dr} T$. $O$. Jones of the US National Science Foundation contains in a couple of short sentences a reference to the recent Agreed Measures on Conservation adopted by the twelve Antarctic powers in pursuance of the Antarctic Treaty of 1961.* As Dr Jones justly says: "They are unusual because this may be the first time in history that man has ever seriously attempted any steps in conservation before it is too late." No doubt the book was written before these measures were promulgated, but their omission is regrettable, since they are of intrinsic interest to many readers although few yet know about them. Moreover, they work.

* See ORYX, April, 1966.

E. M. NICHOLSON.

\section{The Appalachians, by Maurice Brooks. Houghton Mifflin, $\$ 6.95$.}

To the European naturalist visiting them for the first time the smooth rounded appearance of the Appalachians may come as something of a surprise, for the name has suggested to him a range of snow-covered peaks. But they are none the less interesting for being unexpectedly accessible, and include such famous sites as Hawk Mountain, where bird watchers gather in the autumn from far afield to see the remarkable southward migration of raptors. This fine survey by the Professor of Wildlife Management at West Vinginia University is the first in a new series, "The Naturalists' America", edited by Roger Tory Peterson of the United States and Jack Livingston of Canada, which is intended to parallel the "New Naturalist" in Britain. 